\title{
Analysis on Dynamic Game of Island Development under Government Encouragement
}

\author{
LIU Jiayan \& HU Zheng
}

\author{
China Merchants Group a. Postdoctoral Scientific Research Station, Guangzhou, Shenzhen, China \\ Merchants Group, Hong Kong
}

Keywords: Dynamic Game; Island Development; Government Encouragement

\begin{abstract}
Island resources require care and attention from governments and all circles of the societies as a part of China ocean strategies and 'marine silk road'. In the paper, tripartite game behavior of government, island investors and relevant operators is established through evolutionary game model. Strategy equilibrium (ESS) reached by the three parties under the conditions of government incentive policies and none incentive policies is analyzed. Meanwhile, long-term dynamic phase diagram of the tripartite game is concluded. The importance of government incentive policies on island development is concluded through analysis in the paper. Government behavior promotes cooperation between relevant operators with island project investors, thereby forming linkage effect. In the paper, the study has important theoretical significance to island development in China.
\end{abstract}

\section{Introduction}

The 21 st century belongs to a century of ocean. The launch of 'marine silk road' strategy further indicates that China increases rediscovery on value of the coastal areas. (Cai Wu, 2014) Coastal areas have always been the bridgeheads for economic development in China, which guide economic transformation and industrial structure adjustment in China. Coastal land resources have underwent large-scale development and utilization. However, all circles of the society do not pay much attention to development of island resources. (Lu Kun, 2010) There are more than 7000 islands in different sizes in China, and most of the islands have lesser area and inadequate development. Although related regulations and policies about island development have been developed in China coastal provinces,c project delay or improper operation are frequently discovered from the perspective of island development projects. Currently, island development in China is still in the backward level all over the world. Island development has many difficulties and uncertainties compared with development of other land resources. The government should exert own policy incentive mechanism, and promote rational development of island project. Island resource development has important role to China ocean strategy and development of ocean silk road.

Island development always encounters the plight of 'easy island purchase and difficult development'. Most islands keep their original features. Island project development requires high investment in construction and maintenance of traffic, power supply, water supply and other infrastructure, thereby forming high fund demand. Since island area is lesser in china, single islands can't form large-scale operation. Meanwhile, islands are separated from land by natural waters, which is not beneficial for continued operation of island tourism projects. In addition, island project development is also difficult in marine environment maintenance and improvement, etc. (McElroy, J.1 2006). Government policy behavior has important role in island development efficiency in the aspects of breaking through island project development problem and improving the efficiency of island project investment. (Xu Fuying, Ma Bo, Liu Tao, 2014) Government and investors act as the main bodies of strategy interaction in the game process of island project development. The best reflection decision can be made of mutual study on opponent strategies. Meanwhile, the strategy reflection belongs to a dynamic process with continuous adjustment due to short-sighted behavior under limited rationality conditions. Evolutionary game model of dynamic game refers that both parties in the game gradually stimulate through the most beneficial strategies under different strategy behavoirs, thereby finally reaching a equilibrium state (Gartner, W. B 2004). Xu Xiaodi 2010 
and Cui Xiangmin 2013 analyzed the influence of government policy on enterprise independent innovation through evolutionary game model. The importance of government support behavior in enterprise independent innovation is theoretically proved. Island project is also related to a group in the investment process, namely project operators related to island project, such as similar project on the bank land, passenger terminal, etc. Since islands are separated from mainland and other islands by seawater, they are always independent, and natural contact with regions can not be easily formed. Therefore, island development should cooperate with other projects, thereby forming good mechanism of interactive development. Therefore, related operators of island projects also form an important game group. Previous evolutionary game study is basically related to two groups only. However, the , evolutionary game model is extended from two-party game into tripartite game based on specialty of island project investment. Three parties in the game model respectively include island investors, governments and related operators.

\section{Model Setup}

It is assumed that island project investment is mainly related to three groups, the first group refers to investors of island development project, which is represented by A. The second group refers to operators in the industry the same as or similar to the island development project near the coastline, which is represented by B. The third group refers to governments, which is represented by G. The government formulates corresponding development policies and choose to motivate investors of island project development or not according to present situation of island development. For example, the government may stimulate from fiscal, financial, technical and other aspects, thereby leading more investors to participate in island project investment. Operators in the industries the same or similar to island development may cooperate with island project investors for joint development during island project investment according to own interest condition, or they can adopt resistant competition to secure own market shares. The government also can promote cooperation between trade operators and island development investors through incentive means. Therefore, the three groups can form interconnected game process. Figure 1 shows the game tree between policy incentives and investor behaviors.

Specifically, Table 1 and Table 2 clear show the game results under two conditions that the government adopts 'incentive' policies or does not adopt 'incentive' policy in island project development, wherein $\pi_{A}$ represents projects obtained from island project investment; $\pi_{B}$ represents projects of projects the same as or similar to island project; $r_{A}$ represents the additional interests given by the government to the investors for stimulating island development; $r_{B}$ represents additional interests given by the government for stimulating related operators; $r$ represents the interest loss since market shares of operators may be occupied after establishment of island project; $\mathrm{C}_{\mathrm{A}}$ refers to the cost for resisting competition of trade operators; $C_{B}$ represents the cost spent by the trade operator for resisting entrance of island investors; it is assumed that the probability for related operators to adopt competitive behavior is $\mathrm{x}$. Probability of cooperation behavior is 1- $\mathrm{x}$, the probability for investors to enter island project development is $\mathrm{y}$, and the possible of none entrance is 1-y. 


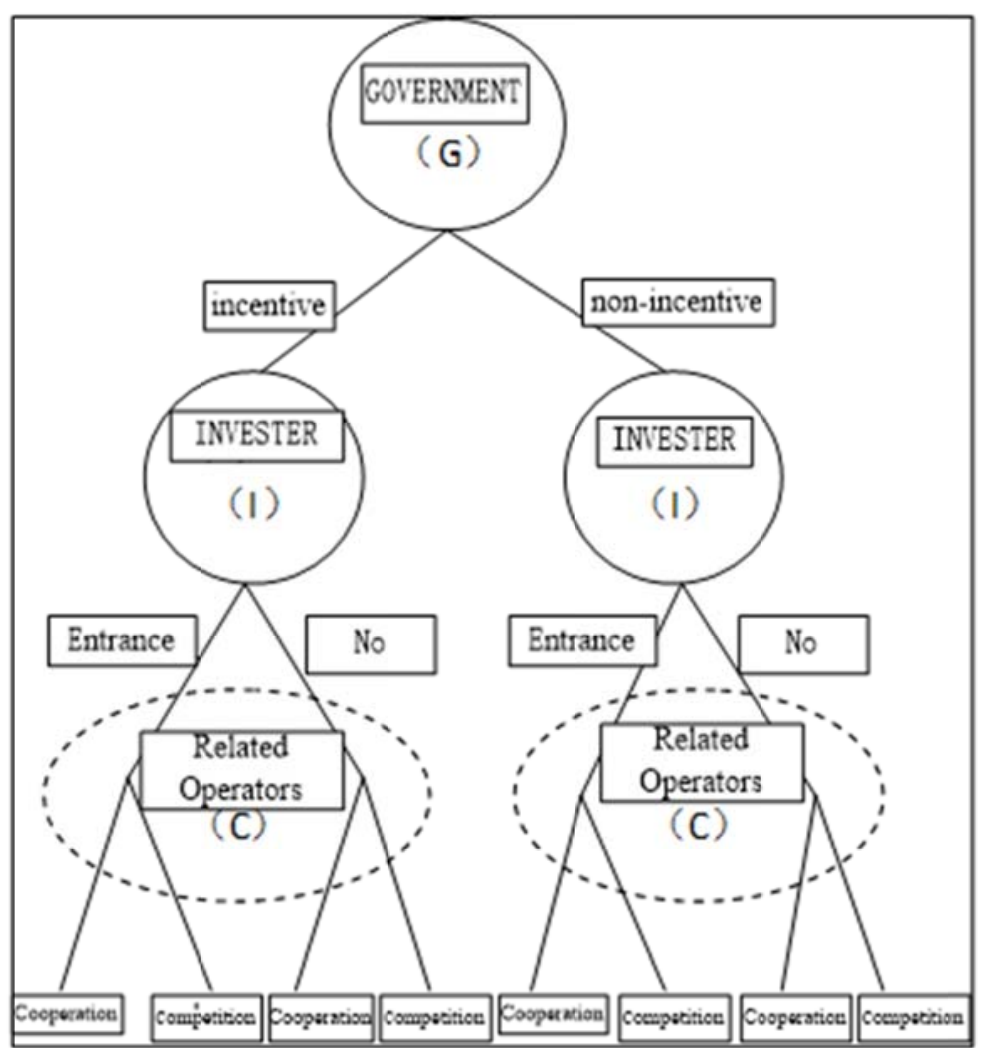

Figure 1. Game tree of policy incentives and investor behavior

Table 1 Island project investment game under government encouragement

\begin{tabular}{|c|c|c|c|}
\hline \multirow{2}{*}{\multicolumn{2}{|c|}{$\begin{array}{l}\text { Government } \\
\text { encouragement }\end{array}$}} & \multicolumn{2}{|c|}{ Related Operators } \\
\hline & & \multirow{2}{*}{$\begin{array}{l}\text { Competition (x) } \\
\pi_{\mathrm{A}}+\mathrm{r}_{\mathrm{A}}-\mathrm{C}_{\mathrm{A}}\end{array}$} & \multirow{2}{*}{$\begin{array}{c}\text { Cooperation(1-x) } \\
\pi_{\mathrm{A}}+\mathrm{r}_{\mathrm{A}}\end{array}$} \\
\hline \multirow{4}{*}{ investor } & \multirow{2}{*}{ Entrance $(\mathrm{y})$} & & \\
\hline & & $\pi_{B}-C_{B}$ & $\pi_{B}+r_{B}-r$ \\
\hline & \multirow{2}{*}{$\begin{array}{c}\text { None } \\
\text { entrance } \\
(1-y)\end{array}$} & $-\pi_{\mathrm{A}}$ & $-\pi_{\mathrm{A}}$ \\
\hline & & $\pi_{B}$ & $\pi_{B}+r_{B}$ \\
\hline
\end{tabular}

Table 2 island project investment game under none government encouragement

\begin{tabular}{|c|c|c|c|}
\hline \multirow{2}{*}{\multicolumn{2}{|c|}{$\begin{array}{c}\text { Government } \\
\text { encouragement }\end{array}$}} & \multicolumn{2}{|c|}{ Related Operators } \\
\hline & & \multirow{2}{*}{$\frac{\text { Competition (x) }}{\pi_{\mathrm{A}}-\mathrm{C}_{\mathrm{A}}}$} & \multirow{2}{*}{$\frac{\text { Cooperation }(1-\mathrm{x})}{\pi_{\mathrm{A}}}$} \\
\hline \multirow{4}{*}{ investor } & \multirow{2}{*}{ Entrance $(\mathrm{y})$} & & \\
\hline & & $\pi_{B}-C_{B}$ & $\pi_{B}-r$ \\
\hline & \multirow{2}{*}{$\begin{array}{c}\text { None } \\
\text { entrance } \\
(1-y)\end{array}$} & $-\pi_{A}$ & $-\pi_{\mathrm{A}}$ \\
\hline & & $\pi_{B}$ & $\pi_{B}$ \\
\hline
\end{tabular}

\section{ANALYSIS ON STRATEGY EQUILIBRIUM OF EVOLUTIONARY GAME}

Evolutionary game model in the paper can be divided into two situations, namely government incentive industrial policy and non-incentive industrial policy. In the process of solving evolutionary game steady-state strategy ESS, the expected return and the average earnings of all parties in the game must be firstly determined. Replication dynamic differential equation should be established. 
Phase diagram can be determined according to replication dynamic differential equation of different game party groups.

\subsection{Government non-incentive policy}

Investors and related operators of island project can not obtain additional interests from government incentives under the condition without government incentive. The expected return $\mathrm{U}_{\mathrm{A} 1}$ and $\left.\mathrm{U}_{\mathrm{A} 2}\right)$ and average return $\left(\overline{\mathrm{U}}_{\mathrm{A}}\right)$ of the island investor 'entrance' and 'non-entrance' strategies are respectively shown in formula (1)-(3).

$$
\begin{aligned}
\mathrm{U}_{\mathrm{A} 1} & =\mathrm{x}\left(\pi_{\mathrm{A}}-\mathrm{C}_{\mathrm{A}}\right)+(1-\mathrm{x}) \pi_{\mathrm{A}} \\
\mathrm{U}_{\mathrm{A} 2} & =\mathrm{x}\left(-\pi_{\mathrm{A}}\right)+(1-\mathrm{x})\left(-\pi_{\mathrm{A}}\right)=-\pi_{\mathrm{A}} \\
\overline{\mathrm{U}}_{\mathrm{A}} & =\mathrm{U}_{\mathrm{A} 1}+(1-\mathrm{y}) \mathrm{U}_{\mathrm{A} 2}
\end{aligned}
$$

Replication dynamic differential equation of dynamic change of the probability for investor group A to adopt 'entrance' policy is shown in formula (4):

$$
\frac{d y}{d t}=y\left(U_{A 1}-\bar{U}_{A}\right)=y(1-y)\left(U_{A 1}-U_{A 2}\right)=y(1-y)\left(2 \pi_{A}-x C_{A}\right)
$$

Because $0 \leq \mathrm{y} \leq 1$, when $\mathrm{y} \neq 0$ and $1,2 \pi_{\mathrm{Ady}_{\mathrm{y}}}-\mathrm{xC}_{\mathrm{A}}>0, \frac{\mathrm{uy}}{\mathrm{dt}}>0$. island investors will select 'entrance' strategy as an ESS; when $2 \pi_{\mathrm{A}}-\mathrm{xC}_{\mathrm{A}}<0, \frac{\mathrm{dy}}{\mathrm{d}}<0$ and island investors will select 'non-entrance' strategy as an ESS.Expected return $\left(\mathrm{U}_{\mathrm{B} 1}\right.$ and $\left.\mathrm{U}_{\mathrm{B} 2}\right)$ and average revenue $\left(\overline{\mathrm{U}}_{\mathrm{B}}\right)$ for related operators to adopt 'competition' and 'cooperation' strategy are respectively shown in formula (5) - (7).

$$
\begin{aligned}
& \mathrm{U}_{\mathrm{B} 1}=\mathrm{y}\left(\pi_{\mathrm{B}}-\mathrm{C}_{\mathrm{B}}\right)+(1-\mathrm{y}) \pi_{\mathrm{B}} \\
& \mathrm{U}_{\mathrm{B} 2}=\mathrm{y}\left(\pi_{\mathrm{B}}-\mathrm{r}\right)+(1-\mathrm{y}) \pi_{\mathrm{B}} \\
& \overline{\mathrm{U}}_{\mathrm{B}}=\mathrm{U}_{\mathrm{B} 1}+(1-\mathrm{x}) \mathrm{U}_{\mathrm{B} 2}
\end{aligned}
$$

Replication dynamic differential equation of dynamic change of the probability for related operator group B to adopt 'competition' policy is shown in formula (8):

$\frac{d x}{d t}=x\left(U_{B 1}-\bar{U}_{B}\right)=x(1-x)\left(U_{B 1}-U_{B 2}\right)=x(1-x)\left(r-C_{B}\right) y(8)$

Since $0 \leq x \leq 1,0 \leq y \leq 1$, when $x \neq 0$ and $1, y \neq 0$ and $1, r-C_{B}>0$, related operator will choose 'competition' strategy as an ESS. When $r-C_{B}<0$, related operator will choose 'cooperation' strategy as an ESS. Replication dynamic analysis on the dynamic change in two groups from formulas (4) and (8) are combined for obtaining the following phase diagram.

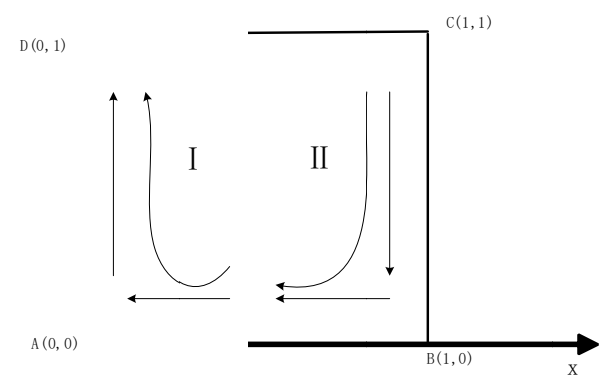

Figure 2. Evolutionary trajectory phase diagram under government 'non-incentive' $\quad\left(r-\mathrm{C}_{\mathrm{B}}>0\right)$ 


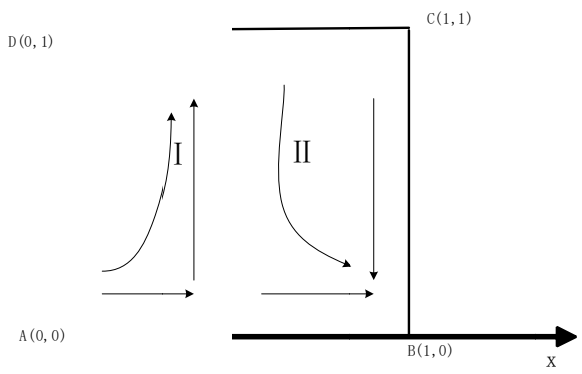

Figure 3. Evolutionary trajectory phase diagram under government incentive 'non-incentive' $\left(\mathrm{r}-\mathrm{C}_{\mathrm{B}}<0\right)$

The above analysis shows that relevant operators choose own strategy mainly depending on the market share of related operators occupied after establishment of island project, consequent interest loss $\mathrm{r}$ and cost $\mathrm{C}_{\mathrm{A}}$ spent for resisting island project investors under the condition that the government does not choose incentive policies. If the profit loss has been far higher than the cost of resistance, relevant operators will choose 'competition' strategy, otherwise they will choose 'cooperation'. However, we pay more attention to the potential behaviors of the island investors. Evolutionary game model shows that if the government selects 'non-incentive' strategies, island investors select to enter the project field depending on returns $\pi_{A}$ of island project investment, undertaken resistant cost $\mathrm{C}_{\mathrm{A}}$ from operators in the trade or related industries. If the return from island project investment is higher and can offset against the cost, the island investors choose 'entrance' strategy. Otherwise, island investors will select 'non-entrance' strategy.

Evolutionary trajectory phase diagram shows that there are two stable strategies that under the condition of the government to take no incentive, there are two evolutionary game stable strategies ESS under the condition that the government adopts 'non-incentive' policy. Firstly, ESS reached by evolutionary game is $(0,1)$ when $r-C_{B}>0$, the phase domain is $2 \pi_{A}-x_{A}>0$, namely when island project investment has enough profits, cooperation of related project operations $(B)$ can be produced, and island project investors (A) can select to enter the field. Secondly, ESS reached by evolutionary game is $(0,1)$ when $r-C_{B}<0$, the phase domain is $2 \pi_{A}-x_{A}<0$, namely when the island project investment does not have enough profits, resistance from related project operators (B) can be produced, and island project investors (B) will select to return from the field. The above analysis shows that the development profits of island project is a decisive factor under the condition that the government adopts non-incentive policy. However, island project development can achieve weak profits, and loss phenomena even can be produced in subsequent development.

\subsection{Government incentives}

Investors and related operators of island project can obtain additional interests from government incentives under the condition of government incentive. The expected return $\mathrm{U}_{\mathrm{A} 1}$ and $\mathrm{U}_{\mathrm{A} 2}$ ) and average return $\left(\overline{\mathrm{U}}_{\mathrm{A}}\right)$ of the island investor 'entrance' and 'non-entrance' strategies are respectively shown in formula (9)-(11).

$$
\begin{gathered}
\mathrm{U}_{\mathrm{A} 1}=\mathrm{x}\left(\pi_{\mathrm{A}}+\mathrm{r}_{\mathrm{A}}-\mathrm{C}_{\mathrm{A}}\right)+(1-\mathrm{x})\left(\pi_{\mathrm{A}}+\mathrm{r}_{\mathrm{A}}\right) \\
\mathrm{U}_{\mathrm{A} 2}=\mathrm{x}\left(-\pi_{\mathrm{A}}\right)+(1-\mathrm{x})\left(-\pi_{\mathrm{A}}\right)=-\pi_{\mathrm{A}} \quad(10) \overline{\mathrm{U}}_{\mathrm{A}}=\mathrm{U}_{\mathrm{A} 1}+(1-\mathrm{y}) \mathrm{U}_{\mathrm{A} 2}
\end{gathered}
$$

Replication dynamic differential equation of dynamic change of the probability for investor group A to adopt 'entrance' policy is shown in formula (12):

$$
\frac{d y}{d t}=y\left(U_{A 1}-\bar{U}_{A}\right)=y(1-y)\left(U_{A 1}-U_{A 2}\right)=y(1-y)\left(2 \pi_{A}+r_{A}-x C_{A}\right)
$$


Because $0 \leq y \leq 1$, when $y \neq 0$ and $1,2 \pi_{A}+r_{A}-x_{A}>0, \frac{u y}{d t}>0$, island investors will select 'entrance' strategy as an ESS; when $2 \pi_{\mathrm{A}}+\mathrm{r}_{\mathrm{A}}-\mathrm{xC}_{\mathrm{A}}<0, \frac{\mathrm{dy}}{\mathrm{dt}}<0$, and island investors will select 'nonentrance' strategy as an ESS.

Expected return $\left(\mathrm{U}_{\mathrm{B} 1}\right.$ and $\left.\mathrm{U}_{\mathrm{B} 2}\right)$ and average revenue $\left(\overline{\mathrm{U}}_{\mathrm{B}}\right)$ for related operators to adopt 'competition' and 'cooperation' strategy are respectively shown in formula (13) - (15).

$$
\begin{gathered}
U_{B 1}=y\left(\pi_{B}-C_{B}\right)+(1-y) \pi_{B} \\
U_{B 2}=y\left(\pi_{B}+r_{B}-r\right)+(1-y)\left(\pi_{B}+r_{B}\right) \\
\bar{U}_{B}=U_{B 1}+(1-x) U_{B 2}
\end{gathered}
$$

Replication dynamic differential equation of dynamic change of the probability for related operator group B to adopt 'competition' policy is shown in formula (16):

$$
\frac{d x}{d t}=x\left(U_{B 1}-\bar{U}_{B}\right)=x(1-x)\left(U_{B 1}-U_{B 2}\right)=x(1-x)\left[\left(r-C_{B}\right) y-r_{g}\right]
$$

Since $0 \leq x \leq 1,0 \leq y \leq 1$, when $x \neq 0$ and $1, y \neq 0$ and $1,\left(r-C_{B}\right) y-r_{B}>0$, related operator will choose 'competition' strategy as an ESS. When $\left(r-C_{B}\right) y-r_{B}<0$, related operator will choose 'cooperation' strategy as an ESS. Replication dynamic analysis on the dynamic change in two groups from formulas (12) and (16) are combined for obtaining the following phase diagram.

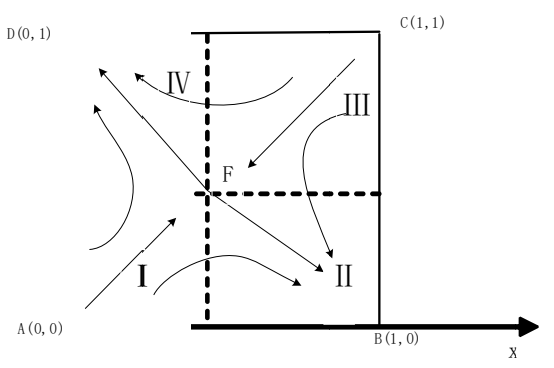

Figure 3. Evolutionary trajectory phase diagram under government incentive

The above analysis shows that island project investors are encouraged by the government on island project investment for obtaining additional return $\mathrm{r}_{\mathrm{A}}$ under the condition that the government selects 'incentive' strategy. Therefore, the strategy for island investors to select 'entrance' into island projects can be increased. Meanwhile, government gives subsidies to related operators, thereby encouraging related operators to select the strategy behavior of 'cooperating' with island investors, thereby reducing the resistance cost $\mathrm{C}_{\mathrm{A}}$ of island operators.

Evolutionary track phase diagram shows that there are two evolutionary game stable strategies ESS under the condition that the government does not adopt incentive, namely B $(1,0)$ and D $(0$, $1)$, which is the same as that under the condition without government incentive. However, $r_{A}$ and $r_{B}$ are added into phase dominant variables under the condition of government incentive policies, which does not merely depend on island development project return ${ }^{\pi} \mathrm{A}$. The probability for the island project investor to select entrance strategy is increased, namely D $(0,1)$ strategy behavior.

\section{RESEARCH CONCLUSIONS AND POLICY RECOMMENDATIONS}

Project investment often requires certain return rate, thereby attracting investors to enter the area. However, island projects are often characterized by high investment, low return and high difficulty in long-term operation. Therefore, it is difficult to support own cost by development return in most island projects. Island project investors select entrance basically depending on island project return under the condition that the government adopts 'non-incentive' policy. This is the reason why there are many island development project delay conditions in China at present, and large-scale island projects are rare actually. Importance of government incentive policy implementation is further ver- 
ified by evolutionary game model, which has direct and importance influence on island project investment.

How does the government to adopt policy for effectively encouraging island project development? Firstly, government support should be given to initial investment on island project, which is mainly embodied in preferential tax policy and establishment of long-term tax mechanism for promoting long-term and sustainable development of island project. Meanwhile, rules and regulations are formulated for guaranteeing and supporting construction of infrastructure, such as island navigation, water supply and power supply, etc. Secondly, island project interactive platform is established, islands often have stronger independence, relevant government agencies should promote 'island linkage' and 'island-mainland linkage' of island project development. One long-term cooperation incentive mechanism should be established for promoting regional interaction of island projects and forming large-scale economy. Thirdly, financial fund support can promote the growth of the island development, which has synergy role on investor entrance and operation development. (Keane M, Ryau M D 2005) Governments should encourage investment of island development funds. Preferential interest rate should be given. Meanwhile, the government should jointly participate in island development projects with investors, such as BOT, PPP and other mode. Fourthly, environmental indicator assessment should be included in important part of island project development. Island ecological environment is related to island project development sustainability. Island regional environmental should be improved and protected. Island project development, especially tourism project development, has long-term correct externality, which is beneficial for sustainable development of island projects (Sonya Graci, Rachel Dodds 2014).

\section{Reference}

[1] Cai Wu. 'Insistence on culture-leading for constructing one belt and one road', Culture Construction and Innovation'. 2014 (9) 44-46.

[2] Lu Kun 'Analysis on particularity and strategy of island tourism development', Social Scientists. 2010 (7): 89-96.

[3]McElroy ,J .1 "Small island tourist economies across the life cycle", Asia Pacific Viewpoint, 2006 47:61-77.

[4] Xu Fuying, Ma Bo, Liu Tao. 'Construction and operation of island tourism sustainable development system-based on the perspective of man-land relationship coordination', Social Scientist. 2014 (7): 82-88.

[5] Gartner, W. B., Shaver, K. G., Carter, N. M., Reynolds, P. D.Hand $\square$ book of Entrepreneurial Dynamics: the Process of Business Creation. Thousand Oaks, CA: Sage, 2004.

[6] Xu Xiaodi. 'Analysis on dynamic game of government support to enterprise independent innovation', Industrial Technology Economy. 2010 (6): 107-110.

[7] Cui Xiangmin 'Research on new entrepreneurs government support based on evolutionary game', Decision-making Reference. 2013 (19) 36-39.

[8] Keane M, Ryau M D. Worlds apart?Finance and in-vestment in creative industries in the Peoples Republic of China and Latin America. Telematics and Informatics.2005, (22):309-311.

[9] Sonya Graci,Rachel Dodds. "Sustainable Tourism in Island Destinations", 2014. 